\title{
安全職場形成のための自主改善活動の 海上労働現場に関する実証的研究
}

\author{
久宗周二*・藤江晋平**・野田一樹***木村暢夫***
}

\section{An Empirical Study on Seafarers of Work Improvements for Safety}

\author{
Shuji HISAMUNE ${ }^{*}$, Shinpei FUJIE* ${ }^{* *}$ Kazuki NODA ${ }^{* *}$
}

and Nobuo KIMURA ${ }^{* * * *}$

\begin{abstract}
It is very important to improve the working condition of a ship by the direct involvement of crew to raise the efficiency of work and to prevent the work accidents. ILO (International Labour Organization) adopted ILO guidelines on Occupational Safety and Health management systems ( ILO-OSH 2001), which aim at providing a practical instrument for policy and work place to improve safety and health at work. WISE (Work Improvements Small Enterprises) training method which is a participatory action oriented training tool has been developed by the support of ILO, and proposes a model guideline to implement the action-oriented, systematic approach to improving safety on board. With the collaboration of crews of Taisei Maru of Institute for Sea Training, we conducted the two-day WISE training. Such steps of the activities are as follows; 1 . A lecture of outline of the group participatory risk improvement activities, 2. Look around the working and living place on the whole ship with action checklist exercise, 3. Group discussion to propose practical improvements, learning the successful examples, 4. Evaluation of effectiveness of these tools.
\end{abstract}

Keywords : ergonomics, human error, safety キーワード:人閒工学、ヒューマンエラー、安全

\section{1. 目的}

日本の船員の労働災害の発生状況は、他の産業に 比べ高い。特に漁船員の労働災害の被災率は高く、 全産業の 8 倍となっている。林業に次いで高い率に なっている。2003 年の漁船員の労働災害を業務上死 亡又は休業 4 日以上（括弧内は業務上死亡）の労㗢 者千人当たりの災害発生率で見ると、漁業は 15.9 （0.8）で、全産業の全産業の 2.6 (0.1) の 6 倍とな っている(1)。
今後、日本の海運業、漁業を継続的に維持・発展さ せていくためには、商船、漁船を含めて、船員・確 保が不可欠な条件ではある。船員の労働災害が多い こと若者が船員職業を選択する際の大きな障害にな ると考えられる。そこで、本稿では、海上における 労働災害防止のための取り組みと、船員の自主改善 活動の推進について検討した。国際条約では、商船 乗組員に適用寸る訓練、資格証明及び当直の基準に ついて、1978 年 7 月に「乗組員の訓練、資格証明及 び当直の基準に関する国際条約の制定(STWC 条粎)

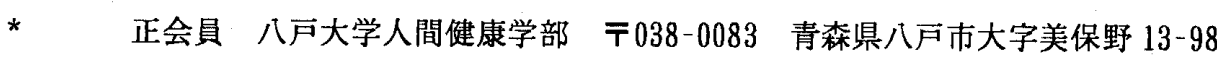

** 正会員 独立行政法人 航海訓練所 $\mathbf{T}$ 243-0003 横浜市中区北仲通 5-57

*** 非会員 独立行政法人 航海訓練所 $\mathbf{2} 243-0003$ 横浜市中区北仲通 5-57

**** 正会員 北海道大学大学院水産科学研究院 $\overline{\mathbf{T}}$ 041-8611 函館市港町 3-1-1
} 
」が国際海事機関（IMO）の総会で採択され、我が 国は 1982 年 5 月にこれを批准し、1984 年 4 月に発 効した ${ }^{(2)}$ 。

現在 ILO（国際労働機関）においては、50を超え る船員の労働基準に係る条約を整理統合し、ILO 海 事統合条約を策定する作業が行われており、平成 18 年には採択される予定になっている。この条約の策 定において、わが国はワーキンググループの中心と なり、積極的に参加しており、他の IM0 条約と同じ く、船員の健康と安全を守る面での国際的な基準と なることが期待される。

陸上産業では、2001 年に ILO が採択した、ILO OSH2001 (産業安全保健マネジメントガイドライン) か、産業安全保健の国際的標準として、わが国でも 現場でそのまま役立つ指針として活用されている。 このガイドラインの中で自主的な安全衛生活動を推 進するために、労働者の参加を本質的な要素として いる。

その特徵としては、

(1) 安全衛生マネージメントシステム。

(2) 継続的な活動。

(3) 誰にでも無理なく、安全で全員参加できる改善 活動。

(4) 改善活動を学ぶためのトレーニングプログラム の作成。

(5) よい改善事例の使用。

(6) 危険有害要因及びリスクの特定と予知・評価。 などがあげられる。

ILO が開発し、ILO OSH2001 に準拠した主改善 活動 WISE (Work Improvements in Small Enterprises ) は、建設や農業を含めて各産業で国際的に成果を上 げている ${ }^{(3-6)}$ 。船内の労働環境の改善に役立てるため、 この IISE の船舶への応用を試みた。特に、アクショ ン型チェックリストは対策選択で “改善提案する”、 “しない”が選択でき、従来の合否型のチェックリ ストに比へて、次の行動がたてや寸いのが特徴であ る。アクション型チェックリストを用いることによ り、潜在リスクの洗い出し、好事例の収集に役立ち、 業場全員の参加を促す等の効果がある。改善に取り 組むことができる環境づくりを提案した。

\section{2. 方法}

海上における労働災害防止のための取り組みの現 状を分析し、WISE 方式の教育手法と運用方法につ いて船舶に応用できるように実証的な研究を行う。 自主改善活動の教育手法と運用方法について船舶に
応用できるように資料を作成するとともに、普及に 向けてのモデル作り、関係機関が連携して安全対策 に取り組み、船舶関係者より評価を受けた。

さらに独立行政法人航海訓練所と共同で、練習船で の自主改善活動の実証実験を行った。

\section{3. 結果}

\section{1 自主改善推進のための啓蒙書の発行}

「海で働く人の改善活動ガイド」(高文堂書店刊) として船員本人が職場の問題点を気づき、改善活動 を推進させることを目的に発行した ${ }^{(7)}$ 。

内容は

(1) 現場に対応した事故調查方法

(2) 安全作業のためのチェックリスト

(3) 事故分析之対策 災害発生状況報告書 記入方法説明

(4) 改善事例集

となっている。

陸上用の ILO チェックリストを、船内作業用に改 善し、自主改善活動の助けになるように、改善事例 集の写真を取り入れた。

\section{2 自主改善推進のための陸上での講習会の開 催}

WISE の講習会を、福岡県北九州市で安全講習会 の一環として実施した。平成 16 年 9 月 8 日に福岡県 北九州市洞海地区船員労衝安全衛生協会の安全講話 「船員災害の防止について」を実施した。30名が参 加し、21 名がアンケートに答えた。参加者の多くは 船舶管理者であった。WISE の解説の後、実際にワ ークショプを実施した。（Fig. 1)

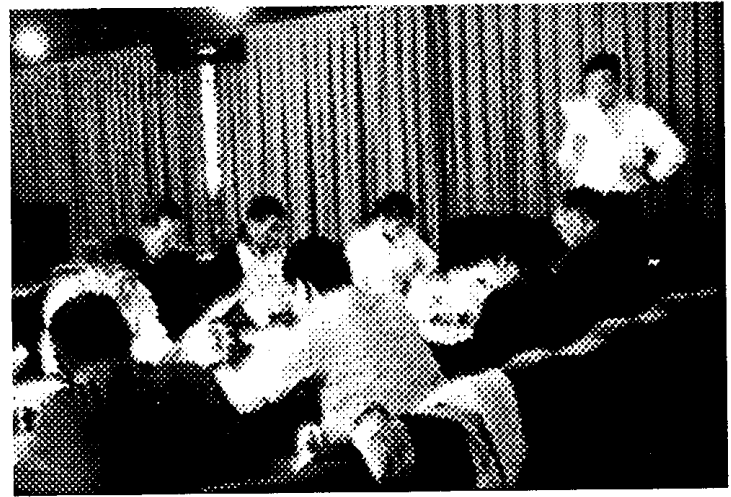

Fig. 1 Safety course at land 


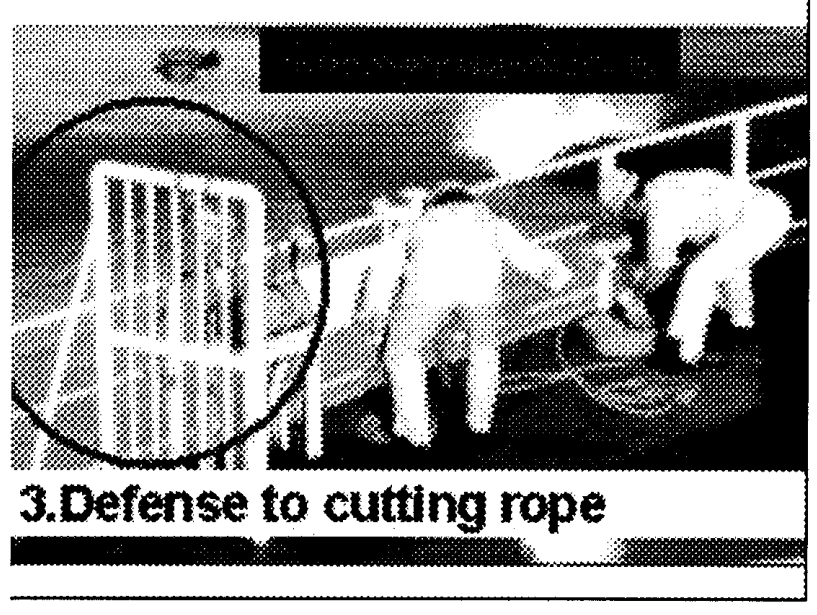

Fig. 2 Sample of work improvement

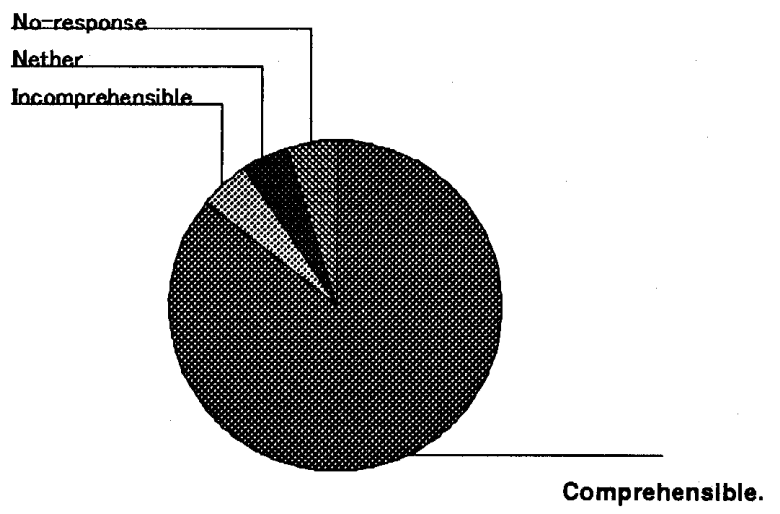

Fig. 3 Impression of course (1)

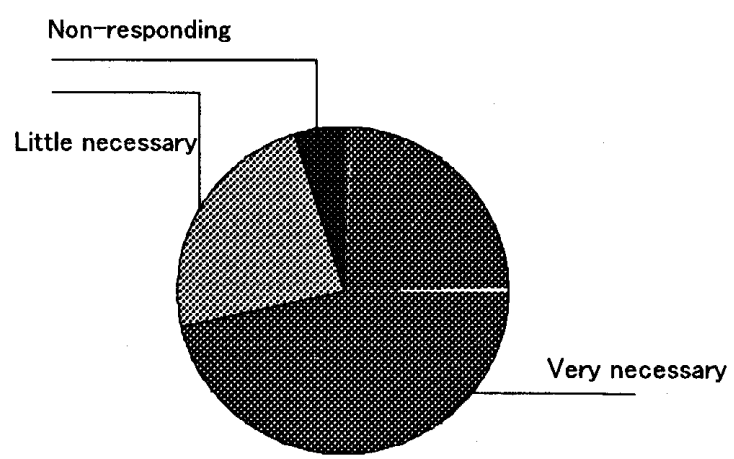

Fig. 4 Impression of course (2)

よい改善事例の選択では、一つは 12 枚の船内での 改善事例の写真を壁に貼り、参加者一人一人が、赤 と黄色のポストイットを一枚ずつもち、一番良いと 思う改善と、2 番目によいと思う改善の写真に張り、 集計した。「ホーサの切断に対する防護柵」(Fig. 2)、 「滑りにくい床塗装」、操作スイッチの配置（の表 示)」などに高い評価が得られた。講習会についての
感想を聞いたところ、9 割の参加者の方から WISE が わかりやすかったとの評価を得た。(Fig. 3)

自主改善活動は船舶で必要かどうか尋ねたところ、 「とても必要」「やや必要」を併せて 9 割近い参加 者の方が必要と考えていた。(Fig. 4) 船内作業で自 主改善活動を行うことは可能かどうか聞いたところ 「可能」「やや可能」を併せて 9 割近くが可能との 意見であった。

\section{3 船上での自主改善活動についての講義}

日時：平成 17 年 8 月 30 日 15 時 $\sim 16$ 時 場所：独立行政法人 航海訓練所 大成丸 5800 総トン

参加者 : 甲板部、機関部の職員、部員 32 名

WISE の解説の後、実際にワークショプを実施し た。よい改善事例の選択では、12 枚の船内での改善 事例の写真を壁に貼り、参加者一人一人が、赤と黄 色のポストイットを一枚ずつもち、一番良いと思う 改善と、2 番目によいと思う改善の写真に張り、集 計した。(Fig. 5) Table 1より「操作スイッチの分 け表示」、「操作スイッチの配置」、「整理された 工具」などに高い評価が得られた。船舶管理者を中 心とした講習会とは、「ホーサの切断に対する防護 柵」、「滑りにくい床塗装」などが高い評価であり、 違いが見られた。

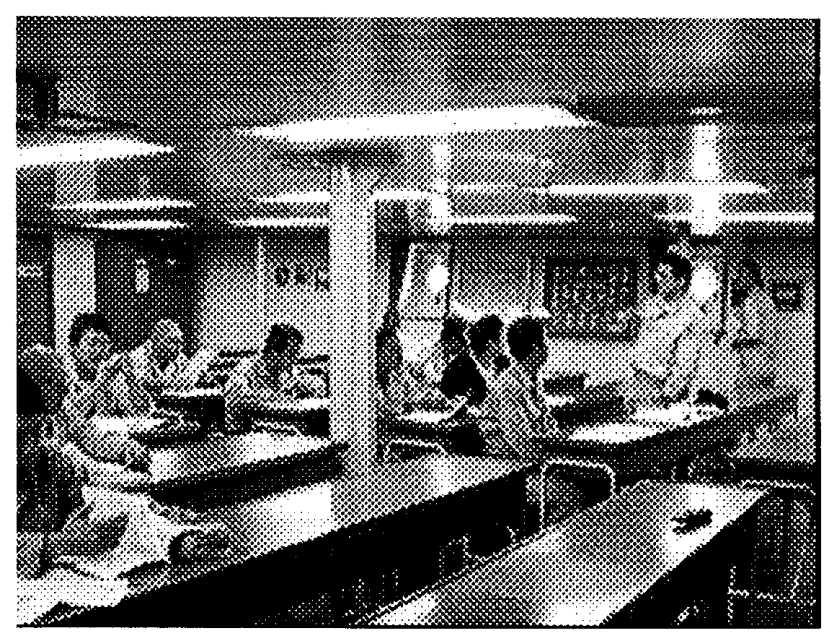

Fig. 5 Safety course in the ship

船上での講習会及の評価では、32 名の回答を得ら れた。職種では、機関部 16 名、甲板部 16 名であっ た。職員、部員別では、職員 13 名、部員 19 名であ った。平均年齢は 38.8 歳、SD11.5 歳であった。 講習会の感想として、「役に立った」14名(43.8\%)、 「役にたたない」1 名(3.1\%)、「どちらでもない」 16 名 $(50.0 \%) 、 「$ 無回答」1名(3.3\%)となった。 
Table 1 The result of workshop

\begin{tabular}{|l|r|r|r|r|}
\hline & sst & 2nd & Total & Merchant \\
\hline Classification display of switch & 10 & 7 & 17 & 5 \\
\hline Arrangement of operation switch & 3 & 11 & 14 & 8 \\
\hline Arranged tool & 4 & 5 & 9 & 0 \\
\hline Work instruction on each port & 6 & 2 & 8 & 7 \\
\hline Floor painting without slip & 3 & 3 & 6 & 12 \\
\hline Spot light at nighttime & 1 & 3 & 4 & 2 \\
\hline Defense of machine & 3 & 0 & 3 & 6 \\
\hline Recreation & 1 & 0 & 1 & 1 \\
\hline Defense ledge to rope cutting & 0 & 0 & 0 & 14 \\
\hline Work instruction & 0 & 0 & 0 & 2 \\
\hline Remote stop button & 0 & 0 & 0 & 1 \\
\hline Display of work stand & 0 & 0 & 0 & 1 \\
\hline
\end{tabular}

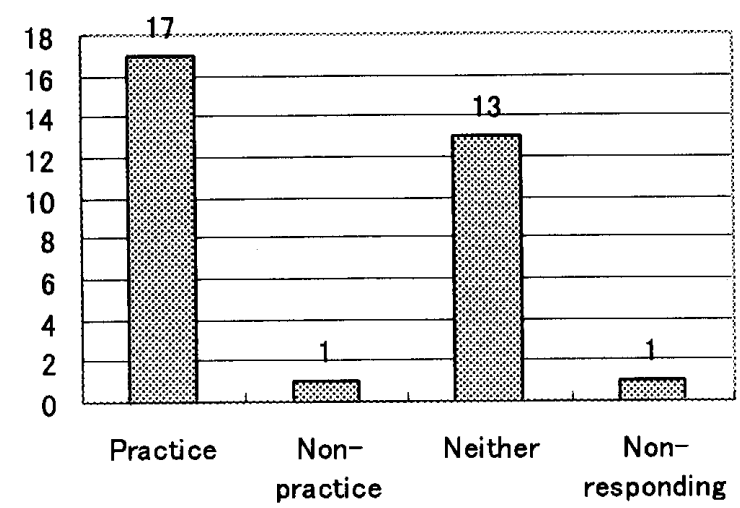

Fig. 6 Answer for "Is the course practicing?"

Fig. 6 より講習会の感想として、「実践的」17名 (53.2\%)、「非実践的」1名(3.1\%)、「どちらでもな い」13名(40.6\%)、「無回答」1名(3.1\%)となった。

「船員の改善活動ガイド」の感想として、「役に立 った」14名(43.8\%)、「役に立たない」1名(3.1\%)、 「どちらでもない」14 名(43.8\%)、「無回答」3 名 $(9.3 \%)$ となった。

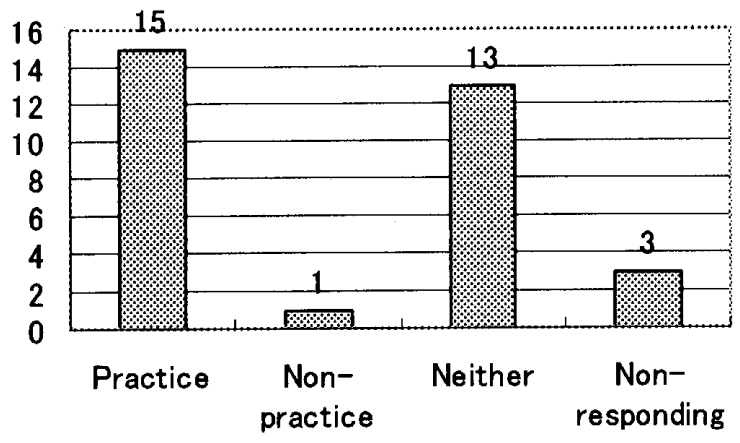

Fig. 7 Answer for "Is the text practicing?".

Fig. 7 より「船員の改善活動ガイド」の感想とし $\tau 、 「$ 実践的」 15 名 $(46.9 \%)$ 、「非実践的」 1 名 $(3.1 \%) 、$ 「どちらでもない」13 名(40.6\%)、「無回答」3名

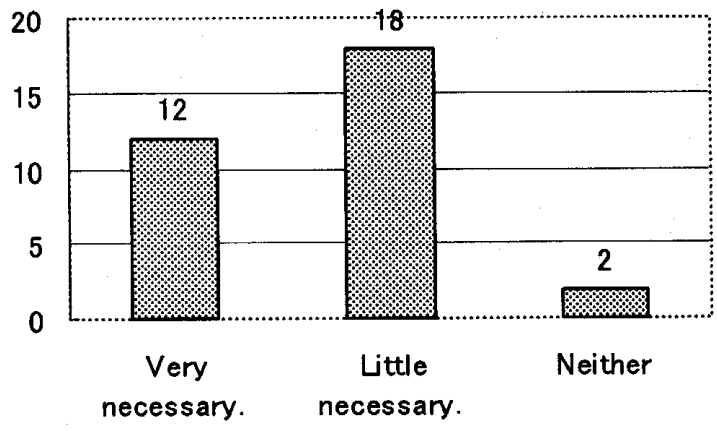

Fig. 8 Answer for necessity of WISE

Fig. 8 より自主改善活動の必要性では、「とても

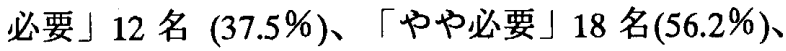
「どちらでもない」2 名(6.3\%)となった。「とても 必要」、「やや必要」を含めて約 9 割以上の参加者 が必要との意見であった。

Fig. 9 より自主改善活動の船内での可能性は、 「可能」 15 名(46.9\%)、「やや可能」 10 名 $(31.2 \%)$ 、

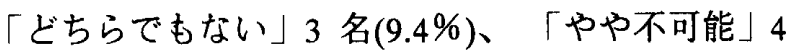
名(12.5\%)となった。「可能」、「やや可能」を含め て約 8 割以上の参加者が可能とした。

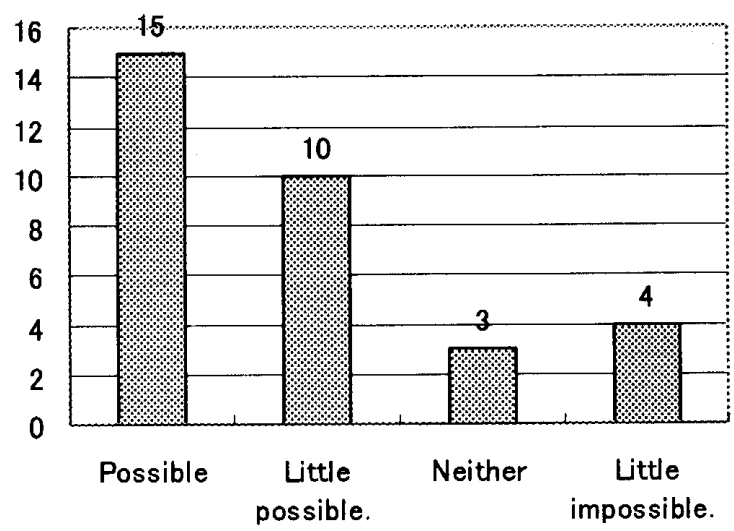

Fig. 9 Answer for possibility of WISE

$(9.4 \%)$ となった。

自主改善活動に関する自由回答では、改善に対す る意識が高揚したなどの意見が多かった。しかし、 自主改善活動の業務が増加することに対する危惧 と、現在の業務で手一杯で改善活動を行うことが難 しいとの意見もあった。資料などをもっとわかりや すく改善することも指摘された。 


\section{4.考察}

海上の労働に関する法律は明治 32 年、船員法や商 法が制定されて、船員の保護監督を規定し、昭和 22 年に船員法が全文改正されたが、船内作業の安全衛 生のための規則は全く定められていなかった。昭和 37 年船員法の一部改正により、一定の船舶について は衛生管理者の選任が義務づけられ、さらに船内作 業により危害の防止と船内衛生の保持を図るための 必要な事項を命令で定めることになり、昭和 39 年 「船員労衝安全衛生規則」が制定された。「船員贸害 防止などに関する法律」(現在「船員災害防止活動の 促進に関する法律」) は、船員災害防止計画を作成、 船員災害防止協会の設立等が規定されている。船員 災害防止計画には、船員災害防止計画之船員災害防 止実施計画があり、両計画とも運輸大臣が船員中央 労働委員会の意見を聞いて策定しなければならない (8)。基本計画は、 5 年ごとに、船員災害の減少目標、 船員災害の防止に関して重点を置くべき事項、船員 災害防止のための主要な対策に関する事項その他船 員災害の防止に関し重要な事項を定める年次計画で ある。船員災害防止基本計画は 5 年毎に完了し、さ らにその中で単年度に事業を設定して実施していく ために数年度にわたる長期的な事業が行いにくい状 況である。そのために、有識者による現場でのヒヤ リング調查が主体であり、実際の作業の分析、具体 的な改善方法の提示まで行っていない事例が多い。 船員労衝安全衛生規則では、作業者は、災害発生の 発生要因に対して、防護、不接近、回避が規定され ており、実際に規則が守られていれば、労働災害の 大部分の事故は防げると考えられている。しかし、 現実には、久宗らは沖合底引き船、巻き網船での研 究の結果より、波浪の影響などは規則が必ずしも守 られていない様々な要因が存在し、労働災害は数多 く発生している(9-10)。船員労働安全衛生規則を遵守 すると実際の作業が滞るなどの障害があり、現場毎 に職務に併せて作業を改善していかなければならな い。久宗らは石灰石運搬船の調查で、現場に適合し た改善案を示しだ(11)。本研究では、船員自らが自主 改善活動を行うことにより作業方法を改善して、作 業現場に対して繰り返し適応し、意見を反映させる ことにより、作業現場で有効な作業方法が生み出せ る手法を検討した。

自主改善活動「WISE」を船内作業に応用する実証 実験を行った。安全衛生マネージメントシステムの 一環として船内に普及させる自主改善活動の教育に ついて船舶に応用できるように資料を作成するとと
もに、船舶関係者より評価を受けた。研究の結果、 船舶での自主改善活動の有効性、可能性が確認され、 自主改善活動に対する意識の高揚が図れた。船舶管 理者と船員では評価が異なり、より有効な資料の作 成、運用に際して船員が負担增にならないような工 夫が必要である。

今後は、実証実験で得られた改善活動成果を分析 する。さらに、航海訓練所と共同で、練習船での安 全衛生に関する実習生の安全衛生関係のカリキュラ 么の中に、自主改善活動手法を紹介できるよう、実 証研究により自主改善活動のカリキュラムモデルを 検討する。

\section{5.まとめ}

IL0（国際労㗢機関）が開発した、自主改善活動 $\lceil$ IWISE (Work Improvements in Small Enterprises)」 方式は、日本を含めた各国の、建設業や農業などの 分野で成果を上げている。船内の労働環境の改善に 役立つ視点が多く、安全衛生マネージメントシステ ムの一環として船内に普及させるために、研究を行 った。研究の結果、船舶での自主改善活動の有効、 可能性が確認され、自主改善活動に対する意識の高 揚が図れた。船舶での自主改善活動を普及すること が必要である。

\section{謝辞}

研究に協力頂いた、独立行政法人 航海訓練所 大成丸乗組員各位、関係各位に心から感謝致します。

\section{参考文献}

（1）国土交通省海上技術安全局船員部:船員災害疾病 発生状況報告(船員法111条)集計書, 1965-2002.

(2)伊勢谷祥三・平野研一·佐藤尚登; 漁船STCW条約 の発効の可能性と海技教育への影響, 海技大学校 研究報告, No.43, pp.1-8, 2000.

（3）ILO (国際労働事務局); 人間工学チェックポイ ント,労働科学研究所出版部, 1998 .

(4) Tsuyoshi KAWAKAMI and Ton That KHAI : Sharing Positive Experiences in Making Changes in Work and Life in a local district in Vietnam, J. Human Ergol, No. 26, pp.129-140, 1997.

(5) Kazutaka KOGI: Advances in Participatory Occupational Health Aimed at Good Practices in Small Enterprises and the Informal Sector Industrial 
Health, No.44, pp.31-34, 2006.

(6) Hidemaro TAKEYAMA et al:: A Case Study on Evaluations of Improvements Implemented by WISE Projects in the Philippines, No.44, pp.53-57, 2006.

（7）久宗周二:海で働く人の改善活善ガイド一船員 労働災害の分析と対策一, 高文堂出版社, 2003

(8) 船災防 20 年史編集専門委員会 : 船員災害防止協 会 20 年史, 船員琰害防止協会, 1988.

（9）久宗周二 ·加藤和彦:船員労働の人間工学的研究 一 I - 一まき網漁業における漁ろう作業の動作分 析一，日本航海学会論文集，No.101，pp.27-334， 1999.8 .

（10）久宗周二:船員労働の人間工学的研究－II . 沖合底曳網漁船における漁ろう作業の動作分析一, 日本航海学会論文集，No.101，pp.253-258， 1999.8 .

（11）久宗周二・天下井清・木村暢夫:船員労働の人間 工学的研究 - II. 船員労働の人間工学的研究 - III. 一荷役作業の動作分析一, 日本航海学会論文集, No.105, pp.43-49, 2001.3.

\section{質疑応答}

世良 亘 (神戸大学) :

改善事象の投票でポストイットを使って張るとい う方法では、他の人の投票行動に影響を受けると思 われますが、いかがでしょうか。

\section{久宗周二：}

ご指摘のとおり、影響を受ける部分があると思い ますが、今回の陸上と海上での結果の違いは参加者 の違い(船舶管理者と乗組員)、船種の違い（貨物船 と練習船)の違いの影響も大きいと考えられます。講 習会の時間が限られているために集団で評価しまし たが、今後検討したいと思います。

\section{長岡 栄 (電子航法研究所) :}

ご発表の表中の点数の味方についてご説明をお願 いします。点数は例えば、各人が 0 か 1 をつけたで しょうか。

\section{久宗周二：}

よい改善事例の選択の表は、参加者一人一人が、 赤と黄色のポストイットを一枚ずつもち、一番良い と思う改善と、2 番目によいと思う改善の写真に張 った数を単純に合計しました。 